\title{
Issues of the Improvement of Anti-Corruption System in Ukraine
}

\author{
Anatolii Movchan *1 [0000-0002-6997-6517], Andrii Babiak 1 [0000-0002-2284-3864], \\ Maksym Movchan 2 [0000-0002-2099-3981] \\ ${ }^{1}$ Lviv State University of Internal Affairs, Lviv, Ukraine \\ ${ }^{2}$ National Police of Ukraine, Kyiv, Ukraine \\ *movchan.anatol@gmail.com
}

\begin{abstract}
Research article analyzes the issues of the improvement of the anti-corruption system, anti-corruption and judicial reform in Ukraine. It is emphasized that the main purpose of anti-corruption reform in Ukraine is to significantly reduce the level of corruption, losses of the state budget and business and to enhance the standing of Ukraine in international rankings. It is noted that a number of issues related to the establishment and functioning of anti-corruption bodies, declaration of property of civil servants, prevention and settlement of conflicts of interest, verification of the righteousness of employees, etc. still remain unresolved. It is emphasized that one of the main components of the formation and implementation of an effective anti-corruption system is a clear interaction of law enforcement institutions at the national and interstate levels. It is noted that it is impossible to effectively fight corruption without an independent judiciary and the Rule of Law. Legislative initiatives of the President of Ukraine in the judiciary also address issues related to the prevention and fight against corruption, in particular: the righteousness of the judiciary, the "reset" of the High Qualifications Commission of Judges and the High Council of Justice. The Venice Commission has repeatedly drawn attention to the need for appropriate legislative changes on these issues. Emphasis is placed on the fact that the urgent task is to change the High Qualifications Commission of Judges, in particular, it is suggested to found a mixed national-international body - the competition commission to select new members of the High Qualification Commission of Judges of Ukraine, and to review the High Council of Justice.
\end{abstract}

Keywords: anti-corruption reform, anti-corruption, anti-corruption bodies, judicial reform, rule of law, virtue.

\section{INTRODUCTION}

Legislation and regulations of Ukraine governing the fight against corruption declare that the main purpose of anti-corruption reform in Ukraine is to significantly reduce corruption, the losses to the state budget and business, as well as to enhance the standing of Ukraine in international rankings assessing [1,2] the level of corruption. The improvement of the effectiveness of the fight against corruption is also one of the main commitments made by Ukraine in cooperation with international financial and other organizations [3].

According to the survey conducted by the Social Group "Rating", EBA, Dragon Capital, CES, FDI and the Razumkov Center, $62 \%$ of respondents believe that anticorruption reform is a priority, 52\% of Ukrainians consider breaking corruption to be strategically necessary for Ukraine's development for the following 10 years. In addition, foreign investors note that "widespread corruption" and "distrust of the judiciary" are hampering Ukraine's economic development. They estimate the impact of these factors on the investment climate as the highest one with indicators of 8.3 and 8.2 points out of $10[4]$.

At the same time, number of issues related to the establishment and functioning of anti-corruption bodies, declaration of property of civil servants, prevention and settlement of conflicts of interest, verification of the righteousness of employees, etc. still remain unresolved. Speaking at the International Forum "Democracy in Action: Zero Corruption Conference", the President of Ukraine V. Zelenskyi stated that the Verkhovna Rada should approve as soon as possible the draft Anti-Corruption Strategy for 2020-2024, which is based on five basic principles: 
optimization of the functions of state bodies and elimination of duplication, digital transformation of the implementation of the powers of public authorities and local governments, convenient and legal services, the inevitability of responsibility for corruption, public intolerance of corruption, the establishment of a culture of righteousness and respect for the Rule of Law [5].

In addition, the President of Ukraine emphasized the need for legislative changes in the judiciary addressing issues related to the prevention and fight against corruption, in particular: the righteousness of the judiciary, the "reset" of the High Qualification Commission of Judges (HQCJ) and the High Council of Justice (HCJ). The need for appropriate legislative changes on these issues has repeatedly drawn the attention of the Venice Commission [5].

At the same time, the President of Ukraine noted that the corruption and oligarchic system in Ukraine did not give up and actively opposed anti-corruption reform.

The president of the Venice Commission J. Buquicchio also spoke at the conference "Democracy in Action: Zero Corruption Conference"; he warned of the possible threat of departure from democratic changes in Ukraine, explained the conditions under which judicial reform will be "doomed", at the same time J. Buquicchio still expressed hope that Ukraine would avoid these risks [6].

Some aspects of the improvement of the anticorruption system in Ukraine were considered in the studies of Akimova L., Bondarenko O., ProkofievaYanchylenko D., Drozd O., Khavroniuk M., Kvasha O., Lapkin A., Lutsyk V., Melnyk M., Novikov O., Parkhomenko-Kutsevil O., Sozansky T., Trepak V., Vozniuk A., Yarmish O. et al.

In particular, the leading areas of research are:

- problems of creation and functioning of specialized anti-corruption bodies in Ukraine [7-11];

- interaction of anti-corruption bodies during the investigation of corruption offenses [12];

- peculiarities of creation and results of activity of the Supreme Anti-Corruption Court [13];

- Ukraine's participation in international cooperation against corruption [14];

- the relationship between anti-corruption reform and judicial reform in Ukraine [15-20].

The purpose of this research is to study current issues of the improvement of the anti-corruption system, anticorruption and judicial reforms in Ukraine.

\section{METHODOLOGY OF RESEARCH}

To perform the tasks of our study, the following methods were used: empirical - for an experimental study; comparative law - for the analysis of regulations governing the fight against corruption, and for the review of researches of scientists and lawyers who have studied this issue.

The method of analysis and synthesis, as well as the logical method have been used to formulate a holistic view of corruption and its features.

The system-structural method was used to determine the institutional features of anti-corruption legislation of Ukraine, the logical-semantic method - to establish the meaning of terms.

\section{RESULTS AND DISCUSSION}

\subsection{Current Issues of the Improvement of the Anti-Corruption System in Ukraine}

According to the vast majority of politicians and scholars, preventing and combating corruption should be a top priority for governments around the world. In particular, in modern conditions the following categories of corruption are distinguished:

1) petty or bureaucratic corruption is carried out by civil servants and lower-level managers who abuse their powers for preferences or small amounts of money;

2) large corruption is perpetrated by business leaders and criminals who settle accounts with key government officials or political parties for economic support in highly profitable sectors;

3) systemic corruption or "endemic corruption" occurs when the state or a private organization establishes rules that allow or encourage corruption;

4) "strategic corruption" is supported and sometimes is organized by the government to achieve political goals or to establish an authoritarian order, where political and economic purposes are inextricably linked [6].

Such institutions of the Council of Europe as GRECO (Group of States against Corruption) and the Venice Commission, in particular regarding the issues of public institutions reform, including the judiciary and the constitutional courts, as well as the creation and reform of anti-corruption bodies, are used to combat the negative phenomenon of corruption.

According to Article 1 of the Law of Ukraine "On Prevention of Corruption" specially authorized entities in the field of anti-corruption are: prosecutors, the National Police, the National Anti-Corruption Bureau of Ukraine (NABU), the National Agency on Corruption Prevention (NACP) [21].

However, the activities of these bodies still have problems related to the gaps in the legal framework; systemic approaches to the activities of anti-corruption subjects and their interaction with each other and with civil society in this area have not been developed, and 
there is no the conceptual vision of organizational and legal support of counteraction to the corruption.

Therefore, D. Monastyrskyi quite rightly notes that one of the main components of the formation and implementation of an effective anti-corruption system is a clear interaction of law enforcement institutions at the national and interstate levels. Comprehensive changes to the CPC of Ukraine are also expected, in particular regarding the introduction of a system of electronic evidence and electronic criminal proceedings [22].

V. Trepak emphasizes that within the general system of state power in Ukraine, two autonomous subsystems of anti-corruption bodies have been created and function; one of them consists of specialized anti-corruption bodies, the other one - of traditional law enforcement bodies and general courts. Such a model raises questions about its effectiveness - support of a proper interaction and coordination of the activities of all anti-corruption subjects, elimination of duplication of their powers, a clear definition of the scope of each body [23].

O. Yarmysh and R. Melnyk believe that the need to create specialized anti-corruption bodies arises when the structural or organizational shortcomings of existing bodies do not allow them to effectively perform preventive and repressive functions of corruption fight [11].

In particular, the National Police of Ukraine has established a special interregional territorial body - the Department of Strategic Investigations, which one of the main tasks is to combat corruption of the officials, identify corruption offenses and stop them.

According to official statistics of the Ministry of Internal Affairs of Ukraine, law enforcement agencies in 2020, 3,693 corruption offenses have been detected. According to the results of the investigation, 3676 criminal proceedings on corruption acts against 2705 people were brought to trial with an indictment [24].

At the same time, it should be noted that the activities of the judiciary are inefficient in dealing with corruption offenses. In particular, according to NABU official information, 405 people were reported as suspects in 2020, 541 people were charged, and 300 indictments were brought to trial. At the same time, the verdict was passed only in 50 proceedings [4].

In addition, the decisions taken by judges of the Constitutional Court of Ukraine (CCU) during 20192020, which relate to the fight against corruption, are of concern to society and our foreign partners. After all, the result of these decisions was a systematic [25, 26] weakening of the institutional capacity of anti-corruption bodies, which led to the release from liability of persons involved in breaking the interests of the state on a particularly large scale.
In particular, the Constitutional Court by its decisions deprived NABU of the right to annul agreements, which were "enslaved" for state-owned enterprises, through a court; in fact it decriminalized illegal enrichment, released entrepreneurs from liability for failure to file a declaration. In general, such decisions of the CCU have forever deprived the compensation of billions of losses caused by corruption [27].

On September 17, 2020, the CCU declared unconstitutional certain provisions of the Law "On the National Anti-Corruption Bureau of Ukraine" regarding the powers of the President of Ukraine. Although this decision does not cancel the establishment and functioning of the National Anti-Corruption Bureau, does not limit the work of detectives and does not call into question the status of NABU as a state law enforcement agency, it threatens the activities of the bureau in the future [27].

In addition, on October 27, 2020, the CCU, at the request of 47 deputies, repealed Article 366-1 of the Criminal Code of Ukraine on penalties for false declarations and several provisions of the Law of Ukraine "On Prevention of Corruption". In particular, the Constitutional Court of Ukraine recognized as unconstitutional the powers of the National Agency on Corruption Prevention to verify declarations of officials, monitor the lifestyle of declaring entities, establish the timeliness of declarations, as well as the provisions on open access to declarations in the Unified State Register. At that time, NABU was in the process of 110 criminal proceedings concerning about 180 cases of intentional entry of inaccurate information into e-declarations by the officials.

In connection with the decision of the Constitutional Court of Ukraine, the President of Ukraine V. Zelenskyi convened an urgent meeting of the National Security and Defense Council, when it was decided to restore public access to the Unified State Register of Declarations and ensure special inspections of the National Agency on Corruption Prevention.

In December 2020, the Verkhovna Rada adopted a generally compromising bill on the resumption of criminal liability. But, as it was mentioned, corrupt officials would not be imprisoned. The maximum sanction of the article is up to two years in prison.

\subsection{Prevention of the Corruption and Reformation of the Judiciary}

An independent judiciary and the Rule of Law is the key to an effective counteraction to the corruption in democracies. Similarly, the independence of the judiciary and the Rule of Law cannot be asserted in the face of widespread corruption.

At the same time, anti-corruption reforms should not contradict the Basic Law, as: 
1) in this case, they can upset the balance between branches of government, which complicates the process of public administration, and sometimes makes it impossible;

2) violation of the Constitution reduces the confidence of citizens in the obligation of the government to adhere to the basic values of the Rule of Law.

In order to solve the problems for further improvement of the judiciary and the administration of justice, the Presidential Decree No 231/2021 of June 12, 2021 approved the Strategy for the Development of the Justice System and Constitutional Judiciary for 20212023.

The strategy establishes the main principles and directions of development of the justice system taking into account the best international practices, in particular, identifies priorities for the improvement of legislation on the judiciary, the status of judges, judiciary and other justice institutions, implementation of urgent measures to improve legal institutions [28].

One of the main purposes of the Strategy is to strengthen the independence of the judiciary and its accountability to the society. In particular, the formation of High Qualification Commission of Judges of Ukraine and High Council of Justice will be based on the results of an open competition held with the participation of international experts.

In addition, the Strategy envisages the improvement of mechanisms for verifying the righteousness of judges of the Constitutional Court of Ukraine and their maintenance of the standards of professional ethics. It is envisaged to change the procedures for the competitive selection of candidates for the position of CCU judge, verification of their righteousness and compliance with the level of professional competence due to the possible involvement of international experts. It is also suggested to introduce a mechanism to protect judges of the Constitutional Court from political and other kinds of pressure when making decisions and conclusions [28].

In a state governed by the Rule of Law, court decisions must be enforced and the independence of judges must be protected. However, judges should be liable to the society due to the system of disciplinary and criminal liability, and they should not be accountable to the executive branch or the legislature. At the same time, judges should have only "functional immunity" in the administration of justice.

However, according to the Venice Commission, the Constitutional Court did not follow its own procedures in reaching its decision on 27 October 2020, some judges had a possible conflict of interest, the CCU's decision was ill-founded and interfered in the powers of parliament. In order to prevent such situations, the Venice Commission proposes to improve the rules governing the activities of the CCU, in particular, on the method of selection of judges of the $\mathrm{CCU}$ and the examination of candidates for these positions with the participation of international experts [6].

On June 3, 2021, during the adoption of the Bill No 4651 the deputies of the Verkhovna Rada amended the bill regarding the change of "imprisonment" to "restriction" of freedom and removed the obligation to declare the property of relatives of civil servants; this is negatively perceived by our foreign partners. The Venice Commission, the European Union Advisory Mission in Ukraine, and the G7 ambassadors expressed their concern over the decision.

In particular, the Venice Commission considers that the dismissal of judges is possible only as a result of appropriate procedures carried out by the High Council of Justice. In addition, it is emphasized that provision of corrupt judges with guarantees of immunity creates the potential for impunity, where corruption thrives even more. Therefore, it is suggested to create a mixed national-international body - a competition commission for the selection of new members of the High Qualification Comission of Judges of Ukraine. It is also noted that the High Qualification Comission of Judges of Ukraine should not be linked to the High Council of Justice until the High Council of Justice has been reformed and its members have been selected. The membership of the High Council of Justice should be reviewed before it is entrusted with the appointment of the High Qualification Comission of Judges of Ukraine [6].

At the same time, the Venice Commission supports Bill No 5068 on the Establishment of an Ethics Council, which will run for six years and will screen candidates before their election or appointment as members of High Council of Justice, as well as it will verify and filter current members of High Council of Justice. The Commission recommends that at least 4 of its 6 members, including two international experts, must vote in favor of the Ethics Council. The predominant weight of the international component should also be in the selection committee to the High Qualification Commission of Judges of Ukraine [6].

\section{CONCLUSIONS AND PROSPECTS FOR FURTHER RESEARCH}

The situation surrounding the activities of Ukraine's anti-corruption bodies needs to be resolved immediately. However, it needs to be seen in a broader context than simply regulation of the legal framework of the National Anti-Corruption Bureau of Ukraine or National Agency on Corruption Prevention. It is necessary to find a legal solution to restore the full activities of anti-corruption bodies. 
Legislative initiatives of the last two years in the judiciary have also addressed anti-corruption issues. These include the righteousness of the judiciary, the High Qualification Commission of Judges and the High Council of Justice, which the Venice Commission has repeatedly called attention to, concluding that judicial reform that did not cover the integrity of High Council of Justice and National Agency on Corruption Prevention members was doomed.

The key to the successful implementation and irreversibility of anti-corruption reform should be the following basic principles of its implementation:

- optimization of functions of state bodies and elimination of duplication;

- digital transformation of the implementation of the powers of public authorities and local governments, convenient and legal services;

- the inevitability of responsibility for corruption offenses, public intolerance of corruption, the establishment of a culture of integrity and respect for the Rule of Law;

- clear interaction of law enforcement institutions at the national and interstate levels in combating corruption;

- righteousness of the judiciary, "reset" of the High Qualification Commission of Judges and the High Council of Justice.

Thus, the improvement of the anti-corruption system is one of the main directions on the way to overcome it.

\section{REFERENCES}

[1] Tkachenko, Volodymyr Kwilinski, Aleksy Korystin, Oleksandr Svyrydiuk, Natalia and Tkachenko, Iryna (2019), “Assessment of information technologies influence on financial security of economy", Journal of security and sustainability issues, march, vol. 8, no. 3, pp. 375385, DOI: $10.9770 /$ jssi.2019.8.3(7)

[2] Korystin, O.Ye. (2020), Chapter 4. State Legal Police of Scientific Prediction. Public administration in the digital economy, monograph, Tallinn, Scientific Center of Innovative Researches OU, DOI: 10.36690 PADE

[3] On the Strategy of Sustainable Development "Ukraine - 2020": Decree of the President of Ukraine of January 12, 2015, vol. 5/2015, Government Courier of 15.01.2015 no 6, available at: https://zakon.rada.gov.ua/laws/show/5/2015

[4] Report of the National Anti-Corruption Bureau of Ukraine for 2020, available at: https://nabu.gov.ua/report/zvit-2020-rik
[5] Hybrid threats to democracy: Zelenskyi spoke at the international forum about the fight against corruption, available at: https://www.ukrinform.ua/ rubric-polytics/3260379-oligarhicna-sistema-nezdaetsa-i-sodna-cinit-opir-zelenskij.html

[6] It will be difficult for judges to accept this: how the justice system in Ukraine should change, available at:

https://www.eurointegration.com.ua/articles/2021/ 06/8/7124199/

[7] Bondarenko, O. Utkina, M. Dumchikov, M. Prokofieva-Yanchylenko and D. Yanishevska, K. (2021), "Review of the state anti-corruption institutions effectiveness in Ukraine", Amazonia Investiga, vol. 10 (38), pp. 219-233, DOI: 10.34069/AI/2021.38.02.22

[8] Lapkin, A.V. (2021), "Specialized anti-corruption prosecutor's office in the mechanism of realization of the state anti-corruption policy" , available at: https://dspace.nlu.edu.ua/bitstream/123456789/12 464/1/Lapkin_259-262.pdf

[9] Parkhomenko-Kutsevil, O.I. (2019), "Formation and development of modern anti-corruption bodies of state power as a basis for preventing and overcoming corruption: theoretical and methodological analysis", monograph, SE "Ed. House "Staff", Kyiv, Ukraine.

[10] Sozansky, T.I. \& Lutsyk, V.V. (2018), "Powers of the National Agency for Prevention of Corruption", Scientific Bulletin of Lviv State University of Internal Affairs, vol. 1, pp. 302-314.

[11] Yarmish, O. \& Melnik, R. (2015), "Specialized Anti-Corruption Institutions: World Experience and National Model", Scientific Journal of the National Academy of the Prosecutor's Office of Ukraine, vol. 2, pp. 144-155.

[12] Mulyar, G. \& Khovpun O. (2019), "Interaction of anti-corruption bodies of Ukraine during the investigation of criminal proceedings", Bulletin of the APSVT, vol. 5, pp. 56-65.

[13] Drozd, O. Nykytiuk, Y. Dorofeieva, L. Andriiko, O. and Sabluk, S. (2020), "High AntiCorruption Court of Ukraine: the peculiarities of establishment and the first results", Amazonia Investiga, vol. 9 (29), pp. 170-178, DOI: 10.34069/AI/ 2020.29.05.20

[14] Bondarenko, O. Reznik, O. Yevgen, G. Andriichenko, N. \& Stohova, O. (2020), "Participation of Ukraine in International Cooperation against Corruption", Amazonia 
Investiga, vol. 9(29), pp. 407-416, DOI: 10.34069/AI/2020.29.05.45

[15] Vozniuk, A.A. (2020), "Unconstitutionality of declaring unreliable information: arguments and counterarguments, in: Implementation of state anticorruption policy in the international dimension", Materials of $V$ International. scientific-practical conf., Kyiv, December 9-10, National Academy of Internal Affairs, part 1, pp. 61-65.

[16] Melnyk, M.I. (2020), “Anti-corruption activity of the state: the problem of compliance with the Constitution of Ukraine, in: Support of law and order in the conditions of the Corona crisis", Materials of the IV Kharkiv International law forum, Kharkiv, September 23-24, pp. 157-166.

[17] Kalitenko, O.V. Kalmykov, D.O. Koliushko, I.B. and et al. (2019), "Alternative report on evaluation of efficiency of state anti-corruption policy implementation", for general ed. Havroniuk, M.I., Moskalenko O.M., Kyiv, Ukraine.

[18] Kvasha, O.O. (2020), "Political will is a necessary condition for effectively combating corruption", Constitutional State, vol. 31, pp. 359-365.

[19] Shcherbakovskyi, M. Stepaniuk, R. Kikinchuk, V. Oderiy, O. \& Svyrydova, L. (2020), "Evidentiary problems in the investigation of corruption crimes in Ukraine", Amazonia Investiga, vol. $9(32)$, pp. 117-124, DOI: 10.34069/AI/2020.32.08.12

[20] Sukhonos, V Pavlenko, L. Krukhmal, O. Ivanovska, A. and Maletov, D. (2021), "Forms of committing corrupt abuses of public finances and ways to counteract them in Ukraine", Amazonia Investiga, vol. $10(39), \quad$ pp. 149-158, DOI: $10.34069 / \mathrm{AI} / 2021.39 .03 .14$

[21] On Prevention of Corruption: Law of Ukraine of October 14, 2014 No 1700-VII (2014), Bulletin of the Verkhovna Rada, no 49, art. 2056, available at: https://zakon.rada.gov.ua/laws/show/1700-18
[22] Monastyrskyi, D.A. (2020), "Greetings to the conference participants. Implementation of state anti-corruption policy in the international dimension", Materials of $V$ International. scientific-practical conf., Kyiv, December 9-10, National Academy of Internal Affairs, part 1, pp. 13-14.

[23] Trepak, V.M. (2020), "Combating "elite” corruption in Ukraine: reasons for inefficiency", Materials of $V$ International scientific-practical conf., Kyiv, December 9-10, National Academy of Internal Affairs, part 1, pp. 269-272.

[24] Anti-Corruption Status Report for 2020, available at: https://mvs.gov.ua/ua/pages/274_Statistika.htm/

[25] Asif A. Laghari, Awais K. Jumani, Kamlesh Kumar and M. Ameen Chhajro (2021), "Systematic Analysis of Virtual Reality \& Augmented Reality", International Journal of Information Engineering and Electronic Business, vol. 13, no. 1, pp. 36-43, DOI: $10.5815 /$ ijieeb.2021.01.04

[26] Malini M. Patil and Basavaraj N. Hiremath (2018), "A Systematic Study of Data Wrangling", International Journal of Information Technology and Computer Science, vol. 10, no. 1, pp. 32-39, DOI: $10.5815 /$ ijitcs.2018.01.04

[27] The constitutional crisis needs an immediate solution to restore the effective work of anticorruption bodies - NABU statement, available at: https://nabu.gov.ua/novyny/konstytuciyna-kryzapotrebuye-negaynogo-vyrishennya-zadlyavidnovlennya-efektyvnoyi-roboty

[28] Volodymyr Zelenskyi approved a three-year Strategy for the Development of the Justice and Constitutional Judiciary, available at: https://www.president.gov.ua/news/volodimirzelenskij-zatverdiv-tririchnu-strategiyu-rozvitku68997 